\title{
РАЗМЫШЛЕНИЯ О КОММУНИКАТИВНО-КУМУЛЯТИВНОЙ МЕТОДИКЕ ОБУЧЕНИЯ ИНОСТРАННОМУ ЯЗЫКУ
}

\author{
Махкамова Гульнара Турдахуновна, \\ Профессор ТашГПУ
}

Ключевые слова: коммуникативно-кумулятивная методика, функиии языка, ментальные структуры, минимум, принциипь обучения, подход, метод и приемы обучения, компетенциия.

В настоящее время все большую популярность приобретают культуроведчески-ориентированные подходы, нацеленные на соизучение языка и культуры, которые и обусловливают введение в научный оборот методики обучения ИЯ соответствующие компетенции (например, социокультурная, межкультурная коммуникативнокогнитивная, лингвокультурологическая). Обобщающей моделью этих компетенций выступает культуроведческая компетенция, которая способствует вторичной социолизации личности.

Активное развитие и внедрение культуроведчески-ориентированных подходов в учебный процесс за последние годы обусловлено необходимостью изучения культурног о компонента в номинативно-функциональном плане, т.е. соизучение языка и культуры как средству общения и приобщения к национальной культуре, как процессу и результату вторичной социализации личности. В этом плане особый интерес представляет коммуникативно-кумулятивная методика соизучения языка и культуры.

Профессор Д.Д.Джалалов в своих докладах на научно-практических конференциях подчеркивал важность внедрения коммуникативно

кумулятивного метода обучения иноязычной культуре, обосновывая это тем, что язык/речь выполняет номинативную, коммуникативную и кумулятивную функции [2008, с. 126; 2009, c. 26]. В связи с этим в рамках данной статьи хотелось бы развить идеи о коммуникативно-кумулятивной методике обучения ИЯ в рамках следующих вопросов:

1. Обосновать объективность формулировки «коммуникативнокумулятивный» метод обучения, поскольку профессор Д.Д.Джалолов дает лишь объяснение важности этого метода и очерчивает проблемы для методистов, связанные с 1) выявлением трудностей в обучении культуре; 2) определением учебного минимума концептов, 3) созданием словаря культурных терминов, 4) разработкой технологии обучения языку и культуре на основе коммуникативнокумулятивного метода и др. [2009, с.27].

2. Обсудить сущность коммуникативно-кумулятивной методики, отвечая на вопрос - это метод или подход к обучению ИЯ?

3. Рассмотреть объективность использования термина «коммуникативнокумулятивная компетенция».

4. Определить принципы коммуникативно-коммуникативной методики обучения.

Нет сомнения, что приоритетной функцией языка является коммуникативная, но важность номинативной и кумулятивной функций также нельзя отрицать. Кумулятивная функция была достаточно обоснована сторонниками лингвострановедческого подхода [Верещагин и Костомаров 1990]. Сущность данной функции заключается в том, что именно в языке накапливается культурный опыт, приобретаемый им за долгие годы его существования. При этом накопление и сохранение культурного опыта организуется в виде ментальных конструктов (концепты, фреймы, 
гештальты, скрипты/сценарии). Эта та национально специфичная информация, которая хранится в памяти и способствует созданию и интерпретации смыслов. Или же, оперируя терминами Е.М.Верещагина и В.Г.Костомарова [1990, с. 25-26], это то сверхпонятийное содержание языковых кодов (лексический фон, или же культурный компонент семантики слова) для восприятия и понимания которых необходима отсылка к указанным формам знаний членами определенной лингвокультуры.

C позиции коммуникативной и кумулятивной функций языка существенными свойствами языкового знака выступает коллекция и информативность [Олейникова 2017]. т.е. получение информации, ее хранение в памяти и еe использование в ходе интерпретации и производства смыслов. При этом номинативная, коммуникативная и кумулятивная функции языка реализуются синхронно, дополняя друг друга в общении. Например, в ходе когнитивной деятельности в рамках изучения ИЯ задействуются следующие уровни [Алмазова 2003].

\section{Уровни в познавательном процессе}

\begin{tabular}{|l|ll|}
\hline Уровень правила & Выполнение речевых действий в соответствии с правилами \\
\hline Уровень значения & $\begin{array}{l}\text { Осознание и понимание значений, употребляемых языковых } \\
\text { единиц }\end{array}$ \\
\hline $\begin{array}{l}\text { Уровень речевой } \\
\text { деятельности }\end{array}$ & $\begin{array}{l}\text { Схема построения высказывания (логика высказывания, } \\
\text { доказательная база) }\end{array}$ \\
\hline $\begin{array}{l}\text { Культурологический } \\
\text { уровень }\end{array}$ & $\begin{array}{l}\text { Осознание того, насколько данная презентация соответствует } \\
\text { культурным нормам носителя языка }\end{array}$ \\
\hline Когнитивный уровень & $\begin{array}{l}\text { Осознание обучаемыми предпринимаемых когнитивных } \\
\text { стратегий, их эффективности, а также возможности оценить свой } \\
\text { языковой, речевой и культурный опыт. }\end{array}$ \\
\hline
\end{tabular}

Именно на этих уровнях происходит реализации всех функций языка в общении и успешность овладения учебным материалом в терминах коллекции и информативности как определенного перечня знаний, навыков и умений, отраженных в составе коммуникативной иноязычной компетенции. Обратимся к перечню умений, описанных Е.Н. Солововой [2008, с.34-35], которые, на наш взгляд, непосредственно соотносятся с коллекцией и информативностью.

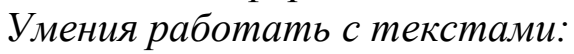

- находить нужную информацию в различных источниках;

- проверить степень достоверности информации с привлечением дополнительных источников;

- работать со справочным аппаратом книги/текста;

- группировать информацию на основе указанных признаков;
- фиксировать нужную информацию в виде записей, тезисов, ключевых слов, плана, конспекта и т.д.;

- понимать информацию на уровне содержания и смысла.

Умения производства собственного текста:

- создавать, именовать, сохранять, архивировать собранную информацию;

- создавать тексты на основе прочитанного, используя ссылки и цитирование источников.

Как видно из указанных умений на уровне рецепции и производства текстов, большая роль отводится кумулятивному аспекту в работе с информацией по ее обработке и сохранению в памяти и отсылки к ментальным структурам для репродукции и продукции текстов.

Bсе описанное выше дает основание утверждать о необходимости наличия когнитивного или же кумулятивного компонента в составе коммуникативной 
иноязычной компетенции. В методической литературе широко используется термины «коммуникативно-когнитивный», «когнитивно-деятельностный» как метод и как подход. На наш взгляд, понятие «кумулятивный» в лингводидактическом плане дублирует «когнитивный» и в тоже время он соотносится с деятельностным аспектом, поскольку посредством общения обучаемые познают мир, т.е. овладевают определенными знаниями, навыками и умениями. Помимо этого, наиболее ярко кумулятивная функция языка как 'хранилище знаний и передача из поколения к поколению' проявляется на уровне усвоения и использования культурно-маркированных единиц языка и поведения, необходимых для интерпретации и производства смыслов в дискурсивной деятельности. Тем не менее, кумулятивная идет в целостности с номинативной функцией языка. Доказательством этому служат примеры 1) фразеологических единиц: to eat dog унижаться, пресмыкаться, быть в унизительном положении, а не «съесть собаку» в значении «приобрести большой опыт»; the old man's friend - пневмония, воспаление легких, а не друг старого человека; to go to west - погибнуть, а не «идти на запад»; wooden shoe - голландец, а не деревянный башмак; или же слово Dutch несет отрицательную коннотацию: Dutch bargain -односторонне выгодная сделка; Dutch comfort (или consolation) слабое утешение; a Dutch concert кошачий концерт; Dutch courage храбрость во хмелю, пьяная удаль; 2) трудностей перевода К. И. Чуковского: Old George - дьявол, а не старый Джордж; Gross - грубый, постыдный, отталкивающий, а не великий и т.д. [Чуковский 2001, с. 25]; 3) сочетания слов: thin soup - жидкий суп, feisty woman мужественная женщина; 4) наличия лакун: во многих языках Африки слово «понимать» отсутствует, его эквивалентом выступает слово «слышать»; 5) несоответствия категории одушевленности и неодушевленности: в английском языке a dog - it; a ship - she (корабль).
Следовательно,

использование термина «коммуникативно-кумулятивная компетенция» является уместным, но кумулятивность должна восприниматься под понятийным ракурсом, а также когниции и метакогниции. В этом случае коммуникативно-кумулятивнуая функция соотносится с процессной стороной эпистомологиии - рост знаний как процесс непрерывного структурирования знаний посредством определенных мыслительных схем, возникающих в результате взаимодействия с окружающим миром [Махкамова 2011, c.23] или же с информации, получаемой в ходе общения.

Таким образом, роль номинативного, коммуникативного и кумулятивного компонентов иноязычной коммуникативной компетенции велика и связываются напрямую с системой смыслов или знаний и умений, которые должны аккумулироваться в ментальных структурах в виде двух тезаурусов, описанных И.И. Халеевой [1989]. Для подтверждения этих утверждений приведем слова Н.Д.Гальсковой: чтобы «понять какую-нибудь фразу или текст, означает пропустить ее через свой тезаурус, соотнести со своими знаниями и найти соответствующее ее содержанию место в картине мира» [2000, с. 69], Представления о мире являются универсальными для представителей определенного сообщества или этноса, а фоновые знания продуцента должны находится в полной корреляции с фоновыми ожиданиями реципиента.

В целях осознания объема тезаурусов обратимся к установкам А.Вежбицкой [1999] о «концепте-максимуме» и «концепте-минимуме», которые описываются автором для осознания разницы между более полным (присущее носителю языка) или менее полным «знанием смысла» (присущее неносителю языка, но достаточное для общения). В объем концепта-минимума (input) должен войти тот перечень «смыслов» в понятийно-функциональном

плане, 
который бы способствовал продуктивной организации дискурсивной деятельности.

Известно, что объем информации (языковой, речевой и социокультурный материал) лимитируется программными требованиями, который увеличивается, либо расширяется от одного этапа к другому этапу обучения. Однако в ходе урока учитель/преподаватель может ввести дополнительную информацию (концепт-максимум) в зависимости от степени сложности материала и когнитивного уровня обучаемых в усвоении этого материала.

Теперь ответим на вопрос, касательно различий между подходом, методом и приемом обучения. В работах E.M. Antony [1963] и J.C.Richards и Rodgers [1990] отмечено, что 1) подход это определенный перечь положений, связанных с природой изучения и обучения языку; 2) метод может быть описан как общий план обучения языку на основе выбранного подхода; 3) приемы - специальные задания, используемые в классе и согласованные с методом и подходом. Таким образом, подход соотносится с теоретической стороной обучения/изучения, а метод - это уровень, в котором теория реализуется/воплощается, прием, в свою очередь, манифестируется в виде методического поступка или задания.

Следовательно, термин «метод» может иметь как широкий, так и узкий контекст, где в широком понимании он ассоциируется даже с подходом, а в узком он может приближаться и к приему. Например: в широком контексте Communicative Language Teaching может восприниматься и как подход и как метод обучения; а в узком контексте project research, problem-solving, и даже brainstorming считаются как методами, так и приемами обучения. Например, project research, problem-solving и brainstorming обычно представлены как задания в учебниках по английскому языку. Как следствие этого, в зарубежной методике идет порой смешивание понятий подход, метод и приемов обучения. Значит, коммуникативно-кумулятивный метод может быть рассмотрен и на уровне подхода и на уровне приема.

Теперь сделаем попытку определить основные принципы коммуникативнокумулятивной методики. Принимая во внимание тот факт, что принципы коммуникативности уже достаточно обоснованы [Richards \& Rodgers 1999; Пассов 1989; Larsen-Freeman 2000; Ankitaben 2015], здесь мы ограничимся лишь принципами кумулятивности. На наш взгляд к принципам кумулятивности можно отнести:

1. Целостность номинативной, коммуникативной и кумулятивной функций языка в общении, что способствует овладению лингвистическим и речевым материалом, осуществлению общения и обеспечению взаимопонимания.

2. Номинативная и функциональная целостность для презентации языковых и культурных феноменов и определения концепта-минимума [Cp.: Green, 2001. p. 10], поскольку лишь номинативный подход не дает возможности определить категории или единицы, необходимые для коммуникации и реализации коммуникативно-кумулятивной методики обучения, т.е. материала достаточного в прагматическом плане. Поэтому в рамках прагматического подхода к обучению (охватывает дискурсивную и функциональную компетенцию), стали учитывать экспрессивную, референтную, фатическую, металингвистическую и конативную функции языка [Green 2001, p.11]. Например, при обучении модальным глаголам следует вводить в коммуникативный минимум не только формальный, но и функциональный аспект модальности, заключающийся в выражении и определении отношения.

3. Коллекция и хранение информации в форме ментальных структур (концепты, фреймы, гештальты, скрипты/ сценарии) или тезаурусов (библиотека значений и навыки интерпретации, репродукции и продукции текстов), или же совокупности субъективащий ценностей, норм, представлений, мировоззренческих 
установок) и объективаций (деятельности, способов поведения, языка, артефактов, усвоенных и используемых в общении).

4. Информативность, которая определяется в двух измерениях: 1) обучаемым необходим тот материал, который несет новые знания достаточные для общения, 2) лексикон и правила оперирования им, информация культурологического плана должна восприниматься как источники смыслов. Обучаемые должны получать информацию не об абстрактных понятиях, а с учетом их семантики и реальных средств выражения мыслей, желаний, чувств и отношения к чему-либо в соответствии с нормами и правилами жанра и изучаемой лингвокультуры.

Таким образом, в рамках данной статьи мы ответили на все поставленные ранее вопросы. Актуальность обозначенных положений, принципов коммуникативно-кумулятивной методики мы видим в отборе минимума «смыслов» и в разработке технологии формирования ментальных структур, необходимых для общения в соответствии с программными требованиями.

\section{Литература:}

1. Алмазова Н.И. Когнитивные аспекты формирования межкультурной компетенции при обучении иностранному языку в неязыковом вузе: Автореф. дис. ... докт. пед. наук. СПб.: РГПУ, 2003.

2. Вежбицкая А. Семантические универсалии и описание языков. - М.: Языки русской культуры, 1999.

3. Верещагин Е.М., Костомаров В.Г. Язык и культура. Лингвострановедение в преподавании русского языка как иностранного. -4-е изд. - М.: Русский язык, 1990.

4. Гальскова Н.Д. Современная методика обучения иностранным языкам: Пособие для учителя. - М.: АРКТИ, 2000.

5. Жалолов Ж.Ж. Чет тил воситасида маданиятлараро мулокотни ўргатиш ёки коммуникатив-кумулятив методика хусусида// Interkulturelle kommunikation - Theory and praxis: Республика илмий-амалий конференция материллари. - Тошкент: ТДПУ, 2008. - Б. $124-127$.

6. Жалолов Ж.Ж. Чет тил ўқитиш замонавий методикасига бир назар// Актуальные проблемы филологии: Материалы региональной научной конференции. - Наманган: НГУ, 2009. - C.25-28.

7. Махкамова Г.Т. Формирование межкультурной компетенции студентов филологического вуза (английский язык): Дис. ... д.п.н. - Ташкент: УзГУМЯ, 2011.

8. Олейникова С.Д. Кумулятивная функция языка в аспекте общения. - Тамбов, 2017.

9. www.tsutmb.ru/nauka/internet-konferencii/2017/6-yazik-kultura.../olejnikova.pdf

10. Пассов Е.И. Основы коммуникативной методики обучения иноязычному общению. - М.: Русский язык, 1989.

11. Соловова Е.Н. Методика обучения иностранным языкам. Продвинутый курс. - М. АСТ - Астрель, 2008.

12. Халеева И.И. Основы теории обучения пониманию иноязычной речи (подготовка переводчика). - М.: Высшая школа, 1989.

13. Чуковский К. Собрание сочинений в 15 т. Т. 3: Высокое искусство. - М.: «Терра Книжный клуб», 2001.

14. Ankitaben A. Desai. Characteristics and principles of Communicative Language Teaching. // International Journal of Research in Humanities \& Social Sciences. Vol. 3, Issue 7. 2015.

15. Antony E.M. Approach, Methods and Techniques// English Learning. Vol. XVII. No 2. - P.63-67. - An Arbor: University of Michigan Press, 1963. 
16. Green A. The theoretical foundations for functions in the Council of Europe modern languages projects and the Common European framework of References for Languages. Cambridge: CUP, 2001.

17. https://assets.cambridge.org/.../9780521184991_excerpt.pdf

18. Larsen-Freeman D. Techniques and Principles in Language Teaching (2nd.eds.). - New York: Oxford University Press, 2000.

19. Richards J.C., Rodgers Th. S. Approaches and Methods in Language Teaching. Second ed. - Cambridge: CUP, 1999.

Maxkamova G. Consideration concerning the communicative-cumulative method of foreign language teaching. In the article the communicative-cumulative method of FLT in the context of the carried out language functions in communication are discussed and principles of this method of teaching are justified.

Махкамова Г. Чет тилини ўқитишда коммуникатив-кумулятив методика хақида мулохазалар. Мақ̧олада чет тилини ўқ̧итишда тилнинг коммуникация жараёнида бажараётган функциялари доирасида коммуникатив-кумулятив методика хฺақида фикр юритилган хฺмда мазкур методиканинг асосий тамойиллари изохланган. 